\title{
ATIVIDADE DE COMUNICAÇÃO E DE TRABALHO
}

\author{
COMMUNICATION AND WORK ACTIVITY
}

Roseli Figaro $^{1}$

Resumo Este artigo discute o binômio comunicação e trabalho a partir da perspectiva da ergologia, ou seja, da atividade humana. Faz uma breve retrospectiva das teorias de comunicação, analisando como as correntes teóricas hegemônicas vêem de maneira limitada os processos de comunicação. E discute sobre os conceitos de comunicação e de trabalho, propondo uma abordagem de pesquisa que permita melhor compreender esse binômio.

Palavras-chave comunicação e trabalho; atividade; teoria da comunicação.
Abstract This article discusses the communication and work binomial from the perspective of ergology, that is, of human activity. It presents a brief retrospective of communication theories, analyzing the limited view of communication processes by hegemonic theoretical currents, and discusses concepts of communication and work, proposing a research approach that will allow better understanding of this binomial.

Keywords communication and work; activity; ergology, communication theory; the world of work. 


\section{Introdução}

Comunicação é uma palavra-chave no mundo contemporâneo. Com ela podem-se abrir inúmeras perspectivas de compreensão da realidade. Este protagonismo da comunicação deve-se à relevância das transformações que se operaram no mundo do trabalho. Explico. As inovações tecnológicas e a reorganização do processo produtivo - em novos patamares não mais necessariamente tendo o modelo fordista/taylorista como paradigma - lastreadas, agora, na produção flexível, própria do modelo toyotista, têm no cerne de seu funcionamento os processos de comunicação. As tecnologias são de informação e de comunicação e a reestruturação do mundo do trabalho fundamenta-se na maior persuasão por meio do aparato ideológico-discursivo em que se baseiam os três pilares do toyotismo: kaizen, kanban e just-in-time. A partir da importância da comunicação, alguns teóricos arvoraram-se em cantar o fim do trabalho, das classes sociais e o nascimento de uma era fundada no diálogo e na ação comunicativa.

Seríamos mais felizes se assim fosse? Talvez. No entanto, frente a tantos desafios, cabe-nos buscar entender a realidade que nos cerca com lentes capazes de focar o problema sem o aumentar, mas também sem o obscurecer.

A partir dessas preocupações, este artigo pretende discutir o binômio comunicação e trabalho na perspectiva da abordagem ergológica. Inicialmente, propomos uma reflexão sobre as teorias de comunicação, tendo como pano de fundo o trabalho industrial e o modelo taylorista de organização do trabalho. A seguir, discutimos o conceito de trabalho, mostrando quanto ele pode ser ampliado se o analisarmos a partir da atividade humana. Em seguida, tratamos do binômio comunicação e trabalho, tendo-o por unidade que nos permite problematizar o papel da comunicação nas relações interpessoais, nas organizações e no conjunto da sociedade contemporânea. Finalmente, discutimos as possibilidades teóricas e empíricas que se abrem ao adotarmos o referencial da ergologia.

\section{Comunicação e trabalho: um terreno de estudos em construção}

As teorias sobre a comunicação apareceram ao longo do século XX, notadamente após a Segunda Grande Guerra, como exigência explicativa das mudanças profundas na vida cultural advindas da presença dos meios tecnológicos de comunicação.

O telégrafo, o telefone, a fotografia, o cinema, o rádio, a televisão são produções do final do século XIX e da primeira metade do século XX. Estas invenções foram impulsionadas pela acumulação de capital, pelo 
crescimento das cidades, pelo modo de vida urbano, pela expansão da imprensa e pela industrialização.

Com as máquinas de comunicar, o homem redimensionou o mundo de maneira a transgredir as noções preestabelecidas de tempo e de espaço. O conceito de comunicação foi potencializado com os sentidos de mobilidade, transporte, ligação, troca, transmissão, contato, fluxo, dando origem a diversas correntes que teorizaram sobre a cultura emergente e as funções dos meios de comunicação.

\section{Transmissão de informação}

Contribuições efetivas foram produzidas nesse campo desde o físico Evin Bauer e o biólogo L. Von Bertalanffy, entre os anos 20 e 30 do século XX, com a teoria dos sistemas. Depois pelos matemáticos Claude Shannon e Warren Weaver, com a publicação, em 1948, de Teoria Matemática da Informação; bem como de Norbert Wiener, definidor de Cibernética como comunicação e controle entre máquinas e homens (1948).

Simultaneamente, tivemos as contribuições, na área das ciências humanas, de Harold Lasswell, nos anos 40, cujo programa de pesquisa definiuse a partir das perguntas: quem?, diz o quê?, como?, a quem?, com que efeitos? Depois Paul Lazarsfeld se dedicou a pesquisas de opinião, sendo precursor dos medidores de audiência. Eles fizeram escola e toda uma corrente de teóricos (Katz, Merton, Berelson, Wright) desenvolveu pesquisas a partir da concepção de função e efeitos dos meios de comunicação. Os teóricos da Escola Funcionalista mostraram com suas pesquisas que os meios de comunicação fazem o agendamento dos temas de discussão na sociedade. Avançaram das primeiras noções de agulha hipodérmica e behaviorista da comunicação direta e individualizada para a noção dos líderes de opinião e do agendamento de temas.

Nos anos 60, o deslumbramento da sociedade com a televisão e com as novas possibilidades de produção da imagem influenciou teóricos tais como Marshall McLuhan, criador da metáfora da aldeia global e da concepção de que os meios são a mensagem. De certa maneira, na atualidade, os teóricos da cibercultura e do pós-humano dão continuidade a essa visão do privilégio das tecnologias em relação ao ser humano.

\section{Crítica social}

Foi na Alemanha que apareceu uma corrente de pensamento crítica aos meios de comunicação. Organizou-se, em 1923, em Frankfurt, o Instituto de 
Pesquisa Social. Em 1931, o instituto passou à direção de Max Horkheirmer e a ser conhecido como a Escola de Frankfurt. Os intelectuais que ali se organizaram discutiam os conceitos de indústria cultural, de manipulação e de poder (Dialética do Iluminismo, 1947) com base na crítica à produção capitalista dos meios de difusão cultural, ou seja, ao uso dos aparelhos e das técnicas de produção e transmissão orientadas pela lógica da reprodução técnica, da massificação e da banalização da cultura e da arte: fotografia, cinema, rádio. É incontestável a contribuição dos pensadores dessa corrente, expressivamente Theodor Adorno, Max Horkheimer e Walter Benjamin. Este último introduziu uma variante crítica ao conceito de indústria cultural por meio de seu mais citado ensaio "A obra de arte na era de sua reprodutibilidade técnica", publicado em 1936, cuja formulação permite separar a lógica da mercadoria da técnica de reprodução do bem cultural. J. Habermas é tido como o herdeiro da Escola de Frankfurt. Ele fez a crítica ao declínio do espaço público, tomado pela lógica do mercado, e desenvolveu conceitos polêmicos como razão comunicativa e ação comunicativa. A Teoria Crítica contribuiu para a análise macro-social crítica da sociedade moderna, inserindo o estudo dos meios de comunicação no cenário da história das relações sociais.

Essas correntes teóricas, de onde saíram diferentes tendências, desenvolveram suas análises tendo como pano de fundo as mudanças trazidas pela introdução de novas tecnologias na produção de bens materiais e culturais. Tais mudanças alteraram a face do mundo do trabalho e deram origem à sociedade industrial. O trabalho industrial, a vida urbana, a formação de grandes cidades, a produção em larga escala para o consumo de massa embasaram as propostas teóricas sobre a Comunicação. A organização científica do trabalho, os métodos de medição do ritmo de execução de tarefas e da capacidade de produção do operário, introduzidos por F. Taylor e, adaptados por H. Ford, na primeira metade do século XX, tinham como finalidades a eficácia do fluxo e da transmissão na linha de produção. Ponto de vista também presente nas análises da Comunicação.

Se fizermos um paralelo entre o pressuposto taylorista sobre o trabalho e as teorias de comunicação, verificaremos que ambos partem de conceitos similares sobre o sujeito. Na linha de produção existe um indivíduo. Aquele que executa a operação mensurada e padronizada por um outro. Para o taylorismo a história pessoal, os valores, a cultura do indivíduo não interessa ao trabalho, eles devem ser obliterados. As operações mecanizadas devem interditar o pensamento. O homem é um operador. Para as teorias de comunicação, advindas das correntes teóricas acima descritas, o mesmo acontece. O fluxo de informação, o canal e o código são prioritários em relação aos sujeitos, tomados individualmente e separadamente de seu contexto sócio-histórico; ou então como massa incapaz de atitude crítica. 
O indivíduo tomado como massa ou como corpo biológico que responde a estímulos não pensa por si, é manipulado pelo poder que emana dos meios de comunicação.

A origem desse pensamento faz parte de uma tradição teórica. E está presente ainda hoje quando se trata de comunicação e de trabalho.

O trabalho, ao longo da história, sempre foi visto pelo pensamento hegemônico de maneira pejorativa, como um mal necessário. Origem de desvalorização e de estigma de lugar social. Na República, de Platão (1991), a cidade ideal é representada sem o escravo, pois este não era tido como ser de sociedade. Na hierarquia social da República perfeita, o topo da pirâmide é reservado ao 'filósofo' e a base ao 'artesão', portador de um saber de ofício. Não existe o termo 'trabalho' para designar a atividade dos que fazem parte da República.

No século XIX, formou-se uma corrente de pensamento que viu o trabalho de um ponto de vista diferente. Marx e Engels deixaram uma produção teórica ímpar na abordagem do trabalho como o maior valor da sociedade. Observaram a História a partir deste conceito e nos deram uma visão completamente diferenciada sobre o trabalho e o trabalhador, inserindo-os como motor da luta de classes. O trabalho produz a riqueza apropriada por poucos. O capitalismo é o ápice da concentração de riquezas. O homem que trabalha é extorquido de seu produto, recebendo por ele somente os meios que lhe permitirão a reprodução de sua sobrevivência. O ser que trabalha, apartado dos bens que produz, apartado da racionalidade dos instrumentos e das máquinas que passaram a portar a síntese do ato, da força e do saber, é analisado como um ser alienado de si mesmo. Muito embora, somente a ação consciente e organizada desses mesmos seres de trabalho possa mudar o rumo da exploração. Marx aproximou antropologia e sociologia para formular sua concepção de materialismo histórico, a partir da qual o trabalho é analisado no percurso da história da humanidade, é o trabalho que cria técnicas e meios de produção impulsionando as mudanças nas relações sociais.

No entanto, não é essa a concepção preponderante de trabalho. O trabalho só merece atenção quando expressa o produto, a técnica ou a tecnologia. Deixa de ser relevante quando cria a prótese e potencializa o instrumento, a ferramenta, ou seja, quando instrumento e técnicas se sobrelevam. Trabalho e técnica são dissociados. Tal dissociação obscurece a presença indispensável da atividade humana, fato que pode ser a origem de interpretações tecnicistas do processo de comunicação.

Nos anos 90, diversas correntes teóricas, ao analisarem a globalização dos fluxos de capitais, as novas tecnologias de informação e comunicação e a nova divisão internacional dos mercados, discutiam e propunham a temática do fim do trabalho. Ao mesmo tempo, retomavam como 
fundamento desse debate formulações sobre a comunicação que nos remeteram aos teóricos do início do século XX, para os quais a comunicação é funcionamento tecnológico e técnico. Desse ponto de vista, as proposições sobre o futuro da sociedade são simplificadas em fórmulas de catástrofes, ou por meio de metáforas, tais como matrix, ciborg, pós-humano, entre outras. Continua-se, portanto, a não compreender o binômio comunicação e trabalho - atitude justificada com a retórica do anti-determinismo econômico e, ao assim se proceder, menospreza-se o processo de comunicação.

Mas o que faz do homem um ser de comunicação?

Responder a esta questão demanda nos posicionarmos contrariamente às abordagens de comunicação apenas como sinônimo de troca de informações, sejam elas de quaisquer tipos: energia, bits, luz, líquidos, alimentação, sinais (concepção da engenharia, da biologia, da bioquímica, da medicina, da física etc.). A Comunicação como área pluridisciplinar, atravessada pelas ciências, é um campo eminentemente do simbólico. Diz respeito às relações entre sujeitos e subjetividades, numa sociedade complexa e tecnológica.

No entanto, o reducionismo do simbólico à linguagem verbal como estrutura autônoma também pode nos levar à incompreensão.

\section{Da língua ao discurso}

O estruturalismo, corrente teórica influenciada pela semiologia, deslocou o estudo da comunicação para a análise da estrutura dos signos. A língua, a partir de Ferdinand de Saussure, fundador da Lingüística, é um objeto de estudo e como tal portadora da estrutura e da organização da comunicação humana específica e superior em relação aos outros animais. Para os primeiros semiólogos, herdeiros de Saussure, a estruturação e o funcionamento da língua é o que interessa à semiologia. A língua foi tomada como objeto de estudo em sua sincronia. A fala, ou seja, o uso da língua por seus falantes, e a diacronia foram elementos inicialmente descartados pelos lingüistas. A mensagem passou ao centro das análises. O interesse era o de saber como o texto se estruturava internamente e de maneira autônoma para expressar o fato. Um texto deveria poder ser descrito sem referências às intenções de seu autor, sem referências sociais ou históricas senão àquelas já presentes no próprio texto.

Roland Barthes, Roman Jakobson, Émile Benveniste são alguns dos grandes nomes que deram vida aos diferentes matizes teóricos originados a partir do estruturalismo. Benveniste (1966, p. 130) ampliou o estudo da lingüística ao afirmar "a língua como 'instrumento' de comunicação, cuja 'expressão' é o discurso". Louis Althusser e Herbert Marcuse influenciaram 
toda uma geração, aproximando o estruturalismo aos conceitos marxistas e à obra de Freud. Foi a Análise de Discursos, a partir de Michel Pêcheux e, depois, com a influência da obra de Mikhail Bakhtin, que recolocou a história e o sujeito na abordagem do texto, entendendo-o como discurso.

Umberto Eco aproximou-se da semiótica e do pragmatismo de Charles S. Peirce, transcendendo a análise do texto verbal para todo o tipo de texto - o verbal e o não-verbal. Todo 'objeto' produzido na sociedade é um 'objeto' para a análise semiótica. Vale destacar, mesmo de forma resumida, que Peirce (2003, p. 46), ao propor sua teoria geral dos signos, definiu signo como "aquilo que, sob certo aspecto ou modo, representa algo para alguém", cuja existência é dada a partir da relação triádica entre o signo, o objeto e o interpretante. Peirce traz para dentro das teorias dos signos o problema da realidade e de seu interpretante. Muito embora, esta questão seja tratada no âmbito da lógica. Para ele, “a lógica é (...) apenas um outro nome para semiótica".

Será a Escola Analítica Inglesa, por meio principalmente de Austin, a recolocar a questão de como se relacionam realidade e linguagem. "Para Austin, há uma realidade objetiva a ser referida e significada..." (Araújo, 2004, p. 128). Essa escola teórica, tal como Wittgenstein, tem como objeto de estudo a linguagem ordinária do cotidiano. Austin, ao situar sua preocupação nos 'atos de fala' da linguagem ordinária, busca classificar os 'diversos tipos de usos de atos de fala'. No afã talvez de provar seu próprio enunciado: dizer é fazer.

A polêmica sobre a importância do 'referente' será a linha demarcatória entre as diferentes correntes da lingüística e da semiótica. O que interessa à abordagem de comunicação e trabalho é a compreensão de que a realidade está na linguagem por meio do percurso sócio-histórico e cultural da experiência humana. Ou seja, a realidade é cognoscível e como tal torna-se realidade fabricada pela capacidade humana de atividade. Diferentemente do objeto da lingüística e da pragmática, para a Comunicação a linguagem interessa pelo seu potencial de dar a conhecer como se estabelecem as redes de relações, quais e como circulam os valores e os pontos de vista nos quais se fundamentam a cultura na sociedade contemporânea.

\section{Culturas e mediações}

É da teoria literária inglesa (F. R. Leavis, década de 1930) que vieram Raymond Willians e Richard Hoggart, fundadores, nos anos 60, da corrente denominada Cultural Studies, do Centro de Estudos de Cultura Contemporânea da Universidade de Birmingham. Além dos dois já citados, Edward. P. Thompson e Stuart Hall também eram membros do grupo de 
pesquisadores que deu início aos Estudos Culturais. A cultura para eles é um conceito de convergência de abordagens antropológica e sociológica. A cultura como 'espírito formador' e 'ordem social global', sistema de significações a partir do qual uma ordem social é comunicada, produzida, vivenciada. Essa combinação destacou o sujeito da comunicação como produtor de sentido, como leitor e elaborador de mensagens; dando destaque para a influência ao grupo cultural e ao meio no qual o sujeito está imerso, e, portanto, considerando-o como um ser pleno de relações.

Essa corrente de pensamento influenciou a abordagem latino-americana da comunicação, representada por teóricos como Jesús Martin-Barbero e Nestor Garcia-Canclini, dando relevância às pesquisas de recepção e ao conceito das mediações culturais. Essa abordagem desloca o interesse dos estudos da comunicação das tecnologias, dos veículos e das mensagens, para tratar das mediações, ou seja, o sujeito e seu meio cultural e social. É aí que acontece a comunicação. Não se trata de audiência, de pesquisa de opinião, de efeitos dos meios de comunicação, trata-se de criação, compreensão, apropriação, reelaboração. O receptor é simultaneamente enunciador e enunciatário das mensagens.

Outras correntes importantes têm enfoque na Psicologia e estão voltadas para o estudo da comunicação a partir das motivações, do funcionamento cognitivo, da dinâmica relacional, dos papéis sociais e dos rituais. O enfoque é eminentemente da comunicação interpessoal. A Escola de Palo Alto é expressão maior dessas correntes. Dortier afirma que:

“designa-se [Escola de Palo Alto] os autores agrupados em torno de Gregory Bateson, Paul Watzlawick e Edward T. Hall, interessados na comunicação interpessoal, na comunicação não-verbal e nas formas de comunicação patológica"2 (Dortier, 1998, p. 19, tradução da autora).

Como se vê, a história do pensamento comunicacional é a história de uma série de correntes teóricas, com contribuições importantes, mas que não articulam o micro ao macro-social à característica pluridisciplinar da comunicação e à sua multiplicidade de objetos de pesquisa.

Em 1985, Dominique Wolton (1998, p. 49-50) escreveu um relatório sob encomenda do Centro Nacional de Pesquisa Científica (CNRS), da França, no qual afirmava que "uma política científica deveria ser impulsionada no setor", mas ao mesmo tempo reconhecia que a comunicação "não pertence a um campo científico específico, é por natureza pluridisciplinar". Ele afirmava ainda que o estudo da comunicação concerne a três grandes setores: neurociências, ciências cognitivas e ciências sociais, bem como a uma série de disciplinas tais como: filosofia, antropologia, sociologia, geografia, história, direito, ciências políticas, psicologia, lingüística e psicossociologia. 
O balanço e diagnóstico sobre os estudos na área, feito por Wolton, também comportavam indicações sobre os diferentes objetos de estudo da comunicação. Ele indicava ao menos sete abordagens para estudo: a primeira seria o que Wolton chamou de comunicação natural, intersubjetiva, entre seres humanos. A segunda seria a comunicação de massa, aquela feita pelos veículos de comunicação: a imprensa, a televisão, a publicidade. Outra seria o campo de estudo relativo à interculturalidade, ou as relações entre identidade e comunicação. Um outro seria o estudo dos efeitos sociais e da história das técnicas de comunicação como, por exemplo, o telefone, a informática, a televisão, a multimídia. Ele afirma ainda que certas questões relativas à comunicação são transversais, caso da retórica e da argumentação, da comunicação pública e comunicação institucional. Um último campo de estudo, para Dominique Wolton, seria o do funcionamento do espaço público e da comunicação política. Finalmente, ele vaticinava:

“a comunicação é um domínio no qual as resistências à análise são fortes, porque cada um já o crê conhecer. É um dos mais promissores canteiros econômicos, culturais e intelectuais do século que se aproxima" (Wolton, 1998, p. 51).

Percebe-se o esforço de Wolton em definir um campo de estudos, os objetivos teóricos e empíricos, mas percebe-se também o quão amplas são as balizas por ele desenhadas.

\section{A abordagem ergológica}

Como afirmamos na introdução, nos situamos nas ciências sociais, nos apoiamos no conhecimento constituído em diversas disciplinas, principalmente na Sociologia, na Análise do Discurso e na Filosofia. Propomo-nos a um estudo pluridisciplinar a partir da abordagem ergológica, ou seja, aquela que prioriza o estudo das ciências e das humanidades, tendo como princípio o ineditismo da atividade humana, o que pressupõe, do ponto de vista epistemológico, a dialética entre os saberes da experiência (savoir investi) e os saberes instituídos (savoir institué). A abordagem ergológica destaca a atividade de trabalho como aquela na qual essa dialética entre os saberes normalizados e o inédito da atividade é capaz de renormalizar a norma antecedente e com isso torna possível trabalhar (conhecer inclusive). É a partir dessa compreensão que tomamos como objeto de estudo a comunicação no mundo do trabalho. Entendemos o sujeito da comunicação como sujeito em atividade de trabalho. Esse desenho de estudo se constituiu porque as pesquisas de recepção da comunicação, a partir do mundo do trabalho, nos trouxeram uma série de novas questões relativas ao sujeito e à produção 
cultural. Mas a principal delas diz respeito à relevância que o mundo do trabalho tem para o sujeito no processo de recepção das mensagens. Ele aparece como lugar de mediação privilegiado e as relações de comunicação se dão de maneira especial. Estudar a comunicação no mundo do trabalho possibilita problematizar a relação do sujeito com sua atividade e com o microcosmo social que é o lugar de trabalho.

\section{Trabalho como atividade humana}

Mas, afinal, o que é trabalho? Qual é a história desse conceito? O que representa o trabalho para a vida humana?

Essas questões foram tomando forma à medida que o estudo de recepção foi nos revelando os sentidos complexos que o trabalho adquire para cada sujeito e grupo social. Uma dimensão profunda e uma perspectiva que nos impulsiona a ultrapassar a definição de trabalho stricto sensu, ou seja, como tarefa realizada em troca de remuneração, numa sociedade regida por leis. Inicialmente foi essa conceituação que emoldurou nossas pesquisas. Mas o discurso do receptor trabalhador foi nos dando uma nova dimensão de sentido para o termo trabalho. Uma profundidade que nos confrontava à concepção trabalho como mercadoria. Dando-nos elementos que exigem uma abordagem mais apurada.

Marx propôs uma compreensão da história a partir do desenvolvimento dos meios de produção, uma análise materialista da história. Em O capital, ele destaca o trabalho como necessidade física da vida humana. Dominique Efros comenta esse aspecto, afirmando que o trabalho é uma atividade humana ("le travail est une activité humaine") e cita Marx:

“O processo de trabalho - a atividade que tem por alvo a produção de valores de uso, (...) é a condição geral das trocas materiais entre o homem e a natureza, uma necessidade física da vida humana, independente por isto mesmo de todas suas formas sociais ou mais precisamente comum a todas elas ${ }^{3}$ (Marx apud Efros, 2002, p. 17, tradução da autora)"

O trabalho é uma atividade que tem por alvo a produção de valores de uso e é condição e necessidade física da vida humana, portanto a relação homem/natureza se objetiva por meio do fazer necessário para a sobrevivência. Dessa forma, o conceito de trabalho transcende a definição que o enquadra como relação de troca remunerada, regida pelo Direito, numa sociedade de mercado.

Borges (2006), citando Schwartz (2000b) e Louboutin (1990), ressalta a dimensão histórica e antropológica do conceito. No período Paleolítico o 
homem passou do trabalho da coleta para a agricultura, marcando a utilização de instrumentos, ferramentas, técnicas para melhor dominar a natureza. No período Neolítico, "surgem as primeiras sociedades de produção" (Borges, 2006, p. 71), passou-se à noção de comunidade, de território a proteger; o mundo agrícola foi ritualizado, apareceram as crenças e os mitos. A natureza passa a ser vista como fonte a ser aperfeiçoada, transformada a serviço de uma coletividade humana. Esse trabalho não era regido por valores monetários, por prescrições alheias à própria atividade. A sociedade de então não dimensionava tempo de trabalho e tempo de não-trabalho. Essa noção não existia. O regime assalariado de trabalho só aparece muito recentemente, entre os séculos XVIII e XIX. Pela primeira vez na história, teremos noção de conceitos tais como: emprego, salário, desemprego, horário de trabalho e horário de lazer. Próprios de uma organização social especializada. Ou seja, a definição de trabalho, mediante troca de valor monetário, restringe-se a uma dimensão do trabalho que é aquela do Direito e do mercado. Se nos restringirmos a essa conceituação, não seremos capazes de compreender a dimensão complexa que existe na atividade de trabalho e, portanto, não avançaremos no entendimento do binômio comunicação e trabalho, restringindo-nos à acepção funcional.

Concepção limitada de trabalho que sequer leva em conta o que Marx sintetizou ao problematizar o homem como um 'ser genérico', fruto da sociedade e da relação com a natureza, o homem é um ser naturalmente social. No Terceiro manuscrito, Marx foi claro quando escreveu:

\footnotetext{
"Mesmo quando eu sozinho desenvolvo uma atividade científica etc., uma atividade que raramente posso levar a cabo em direta associação com outros, sou social, porque é enquanto homem que realizo tal atividade - como também a própria linguagem que o pensador emprega - que me foi dado como produto social. A minha própria existência é atividade social. Por conseguinte, o que eu próprio produzo é para a sociedade que o produzo e com a consciência de agir como ser social" (Marx, 1993, p. 95).
}

Ou seja, mesmo quando trabalho sozinho, minha atividade é social. E o que isso verdadeiramente quer dizer? Como ao trabalhar o homem se faz um ser de sociedade? Essa é a questão que nos remete a problematizar trabalho e comunicação, eixos de uma mesma construção social, a da 'humanidade' do homem.

A abordagem ergológica ${ }^{4}$ permite situar de maneira complexa o conceito de trabalho porque o remete à atividade humana. Ergon, do grego, ação, criação, obra de arte, dá dimensão criadora à 'atividade humana'. Nesse sentido, o trabalho é criação fruto da relação do homem com seu 
meio. É atividade. Atividade (em alemão, tätigkeit) é um conceito pouco utilizado e muitas vezes substituído por ação, o que pode levar ao desvirtuamento, reduzindo-o ao ato que tem um início e um fim temporal, bem como finalidade. De outro modo, ação, para Aristóteles, é própria do discurso, do cidadão, da política. Está na esfera da ética e da moral.

A atividade comporta a noção de movimento, de continuidade, de transformação e de relação. Para Yves Schwartz é em Kant que se pode encontrar a aproximação do conceito de atividade tal qual ele é utilizado na ergologia, ou seja, a "arte escondida no interior da alma humana" (Schwartz, 2000c, p. 14).

Com essa afirmação Schwartz nos remete a Léontiev que, em Le developpement du psychisme, trata atividade como: "activité vitale" (1976, p. 13), mediadora, nos seres vivos, desde os mais elementares, das relações entre os organismos e as propriedades do meio do qual dependem a conservação e o desenvolvimento de sua vida. Estas palavras iniciais de Léontiev permitem compreender a especificidade da vida animal e especialmente da vida humana.

Para os animais a atividade, qualquer que seja ela, é estritamente instintiva, vinculada às necessidades vitais. "Assim, a atividade dos animais fica sempre no limite de suas afinidades biológicas, instintivas, com a natureza. É uma lei geral da atividade animal" (Léontiev, 1976, p. 55, tradução da autora) $)^{5}$. A estrutura dessa atividade animal não leva a respostas que resultem em organização coletiva das atividades deles, ou seja, à vida em sociedade.

Léontiev cita exemplos de estudos sobre as formigas e as abelhas para reafirmar que entre elas não existe organização social e divisão de trabalho nem mesmo comunicação na acepção humana, o que existe é uma diferenciação funcional biológica.

“(...) autores pensam que existe entre certos animais uma divisão do trabalho. Geralmente eles invocam os casos bem conhecidos da vida das abelhas, das formigas e de outros animais "sociais". Na realidade, em nenhum desses casos há real divisão do trabalho, do mesmo que não há verdadeiro trabalho, processo que é social em sua essência"6 (Léontiev, 1976, p. 58, tradução da autora).

A atividade humana é uma atividade particular que dota o homem de um psiquismo específico, caracterizado por propriedades fundamentalmente diferentes. A passagem à consciência humana está fundada na passagem às formas humanas de vida e de atividade de trabalho. Léontiev afirma:

"No mundo animal, as leis gerais que governam as leis do desenvolvimento psíquico são aquelas da evolução biológica; quando se chega ao homem, o 
psiquismo é submetido às leis do desenvolvimento sócio-histórico"7 (Léontiev, 1976, p. 61, tradução da autora).

Para Léontiev, a aparição do trabalho é intrínseca à condição da existência do próprio homem. A atividade humana é particular e específica e caracteriza a capacidade humana de criar, planejar, aprender, memorizar.

Orientamos nesse sentido a citação de Kant feita por Schwartz. A essência humana é dada pela forma particular de sua atividade. Para a abordagem ergológica, a atividade humana é a manifestação da vida humana. O trabalho em sentido amplo é tomado como atividade humana, capaz de transformar o meio em um meio humano.

A ergonomia de língua francesa deu expressiva colaboração para se pensar a atividade humana ao tomar como objeto de estudo o trabalho na indústria e nas organizações contemporâneas. Seus estudos verificaram que, entre o trabalho prescrito pelas normas antecedentes (manuais, regras de utilização de materiais e máquinas, divisão e organização do processo de trabalho) e o trabalho realmente realizado, no momento exato de sua realização, existe uma 'distância' (lacuna) (A. Wisner). Esta distância é o dado inusitado do trabalho, é fruto da 'gestão' própria, de 'si mesmo', do ser humano que trabalha, resolvendo os confrontos impertinentes à situação real de trabalho. Essa distância é a prova da particularidade da atividade humana de trabalho. Melhor dito nas palavras de Perrier:

"É na distância (lacuna) entre prescrito/real do trabalho que os ergonomistas observaram um processo universal de gestão do aleatório, do incidental: a atividade em geral. Sua forma poderia ser concebida como trabalho no sentido de uma tensão para ajustar permanentemente os constrangimentos prescritos antecipadamente (normas, obrigações, objetivos) aos recursos reais disponíveis (meios, reservas subjetivas, escolhas, valores) assim como às situações encontradas"8 (Perrier, 1997, p. 116, tradução da autora).

Para Schwartz, se tratarmos do trabalho apenas como 'emprego assalariado', tiraremos desse conceito a complexidade inerente à atividade humana. Ele afirma que:

“Tratando do valor trabalho (...), arrisca-se a todas as derivações se se esquece que ele não é uma realidade simples, historicamente datada, susceptível de caracterização unilateral. Se o trabalho for identificado, sem nuances, a emprego, se valorizaria o trabalho pelo fato de haver um lugar dentre o conjunto de lugares que definiria uma sociedade. Esta definição puramente exterior valoriza a integração a tal sociedade e rebaixa os conteúdos e os processos de toda a ativi- 
dade humana, assalariada ou não. Por isso, entre uma ação humana qualquer - trabalho autônomo, trabalho doméstico, atividade lúdica, esportiva - e um trabalho economicamente qualificado, não há descontinuidade absoluta: todos os dois são comensuráveis a uma experiência, aquela de uma negociação problemática entre as normas antecedentes e as normas dos sujeitos singulares, sempre a redefinir aqui e agora (...)"9 (Schwartz, 2000c, p. 306, tradução da autora).

Nessa acepção, trabalho é atividade humana que comporta uma herança cultural e histórica das técnicas, da experiência das gerações passadas e da experiência pessoal, o que permite ao homem uma transcendência criativa.

Yves Schwartz também afirma que "toda a situação de trabalho é singular"10. Dessa forma, o uso que o sujeito faz de si no trabalho é singular. A consciência da singularidade do uso de si próprio permite a objetivação e a desnaturalização das atividades de trabalho. O sujeito no trabalho coloca-se por inteiro em atividade. Ele põe em movimento a energia de seu corpo, seus sentidos, sua experiência física e intelectual - o corpo em relação ao meio, aos instrumentos e técnicas. Ele também aciona suas relações com o meio social, seus parceiros de trabalho, os colegas, os chefes e superiores. Convoca também as relações com seu grupo social: a família, o bairro, sua história de vida. Como afirma Jacques Duraffourg (2003, p. 33, tradução da autora): "Não se pode postular a independência da vida de trabalho em relação à vida pessoal das pessoas; é um todo indissociável no qual todas as partes comunicam-se de maneira permanente (...)"11

A ergologia propõe-se a se aproximar desse mundo complexo que é o homem e sua atividade de trabalho. Complexidade desconsiderada pelo taylorismo, pela chamada organização científica do trabalho e mesmo pelo toyotismo. Para Duraffourg (2003, p. 54, tradução da autora), "trabalhar será sempre questão de confrontação da inteligência humana às incertezas do momento presente"12.

\section{Sujeito como corpo-si (corps-soi)}

Trabalhar, no sentido ergológico, é gerir um conjunto de fatores presentes em um determinado momento e espaço, em benefício de um objetivo a construir. Schwartz (2003, p. 80) afirma que "trabalhar é gerir (travailler c'est gérer)". É, sobretudo, administrar-se como sujeito em atividade, ou seja, fazer uso de si como corpo físico e como si (soi). Nas palavras de Schwartz, corps-soi. Essa maneira de abordar o sujeito permite mais bem compreender a complexidade que envolve a atividade de trabalho. 'Sujeito' é um conceito muito desgastado na visão de Yves Schwartz e incapaz de revelar o que lhe é inerente. Por isso, adota corpo-si. Corpo-si, como físico que apreende o 
conjunto de forças que propicia a vida, a condição de Ser Vivo que se relaciona com seu meio físico. E corpo-si como história pessoal, a herança cultural, a consciência, a razão particular contida em cada ato. Nas palavras de Schwartz:

“O corpo-si é a história, a história da vida, da espécie, da pessoa, é a história dos reencontros sempre renovados entre um ser em equilíbrio mais ou menos instável e uma vida, social, com seus valores, suas solicitações, seus dramas. O corposi é história, história como memória sedimentada, organizada nas miríades de circuitos da pessoa; mas também história como matriz, energia produtora do inédito: na medida em que a finalidade renormalizadora é às vezes imposta ao ser - o meio 'infiel'; como 'reencontro' reclama que se escolha se escolhendo tal ou qual maneira de tratá-lo - e, ao mesmo tempo, requerido como exigência de vida, como apelo nele de saúde, utilizando-o sem repouso para tentar transformar o que é objetivamente para ele meio (ambiente) (umgebung) no que poderia torná-lo o seu meio (ambiente) (Umwelt). (...)"13 (Schwartz, 2000c, p. 664, tradução da autora).

A atividade põe em movimento o corpo-si como unidade capaz de revelar a história de longa duração inscrita no corpo humano e da inteligência da mobilização de saberes construídos pelas gerações passadas; e em sua especificidade, como pessoa, indivíduo de um tempo determinado, com uma trajetória particular.

Georges Canguilhem (2006), médico, filósofo, nos ajuda a pensar o corpo-si numa perspectiva inovadora do que seja saúde e do que seja doença. Ele introduziu a idéia de que o 'meio ambiente é sempre infiel' ao ser humano; e a capacidade de se relacionar com esse meio, tornando-o favorável, portanto, construindo um meio humano, normalizando e renormalizando-o a seu benefício, é status de saúde. Para o autor, ter 'saúde é ser capaz de correr riscos. A doença é a incapacidade de mudança ao se confrontar com o meio infiel'. Essas afirmações nos permitem entender mais objetivamente a atividade de trabalho como gestão do corpo-si. Atividade sempre inusitada, pois só existe no momento do confronto do homem com o meio onde ele vive.

A atividade de trabalho é o momento maior de expressão da capacidade do corpo-si. É na atividade que o corpo-si completa-se. Na atividade de trabalho, o corpo-si revela-se como um ser particular e um ser social. Revela o si como o próprio e o si contribuição do outro que reside na nossa história.

Schwartz afirma ainda que:

“(...) a vida, mais precisamente a atividade, e bem mais explosivamente ainda a atividade industriosa, não se prestam a essa legibilidade dócil. (...) A atividade 
de trabalho propõe, convoca, impõe escolhas e arbitragens"14 (Schwartz, 2000c, p. 81, tradução da autora).

Para ele, "analisar a atividade implica um modo de acesso aos valores" (Schwartz, 2000c, p. 820). Dessa afirmação, compreendemos que a atividade de trabalho se desenvolve num chão de valores, sobre o qual as escolhas se operam. Cada pessoa em atividade de trabalho faz escolhas, desde as restritas ao âmbito de seu próprio corpo em movimento; até aquelas que demandam e envolvem a vida e o futuro de outras pessoas. Essa responsabilidade tornada consciência teria, talvez, conseqüências bastante positivas para a vida em comum, para o viver bem em conjunto com outros.

Schwartz (2003, p. 261, tradução da autora) chama de 'dramáticas do uso de si por si mesmo e por outro' 15 o uso que fazemos de nós mesmos e o uso que 'o outro' faz de nós para a execução do trabalho. Entendemos por 'dramática' o movimento entre norma prescrita, infidelidade do meio, re-normalização e atividade singular. Esta contradição inerente 'a toda' a atividade de trabalho, própria da vida, é potencializada pelo conflito entre as diferenças socioeconômicas, pela apropriação mercantil do trabalho, pela exploração, pela desvalorização do trabalho. A contradição e o conflito são geridos e negociados a todo o momento, isso é a atividade humana, é o corpo-si, expressando-se na dimensão dialética do micro e macro-social. Atividade humana afeita, portanto, ao movimento da história.

Está na história de longa e de curta duração16 o nexo explicativo da atividade humana de trabalho. É na história que se pode recuperar o registro do percurso da espécie no processo de humanização; as marcas estão no corpo e no psiquismo específico do ser humano, como bem salientou Léontiev. Fora da história, a atividade humana torna-se incompreensível. A atividade humana no percurso da história resulta do coletivo, da vida social e da experiência particular de cada ser. É o movimento dialético inerente à experiência humana coletiva de longa duração e à experiência particular de cada ser no percurso de sua vida que garantem o ineditismo da atividade humana. Vem daí o caráter de imensurabilidade - que não se pode medir matematicamente - da realidade, cujo conhecimento está sempre em processo.

Hoje, os manuais que prescrevem novas maneiras de gestão das pessoas continuam cegos para a especificidade da atividade de trabalho. Ambicionam persuadir retoricamente os sujeitos no trabalho, convocando a criatividade e a colaboração deles no sentido do apaziguamento dos conflitos potencializados pelas injustiças do sistema econômico, do desemprego, e pelo absoluto desprezo pela experiência de quem trabalha. Os compêndios que tratam da 'comunicação interna' das empresas ou organizações são a 
prova dessa ambição. Por outro lado, as entidades de defesa dos direitos dos trabalhadores têm sido insensíveis a essa dimensão complexa da atividade de trabalho. Suas estratégias de luta não levam em consideração que é preciso haver maior sintonia entre como os sujeitos assumem o desafio cotidiano inerente à atividade de trabalho ao nível micro-social e como se mobilizam para ações 17 que estão no âmbito da política e da participação ${ }^{18}$ social. A comunicação é um vasto campo a ser estudado no âmbito da atividade de trabalho devido à sua capacidade de mobilização e emancipação.

A partir dessas reflexões, podemos afirmar que a abordagem ergológica nos permite tratar de comunicação e trabalho como um binômio fundamental da atividade humana e, nessa perspectiva, entendemos que comunicação e trabalho se completam.

Quando a chamada reestruturação produtiva transformou o mundo do trabalho, por meio da introdução da informatização, robotização, e por meio de novos métodos de organização do trabalho, um conjunto de novas palavras desembarcou nas empresas: 'colaborador', 'cliente', 'competência', 'autonomia', 'criatividade', 'inteligência', entre outras. Tal como se a adoção desse novo vocabulário pudesse por si própria alterar as relações que se dão no mundo do trabalho. Esta é uma visão limitada de comunicação. Continua a tratar, como no taylorismo, de forma autoritária o mundo do trabalho e a menosprezar a capacidade do trabalhador. A atividade de trabalho requisita o homem por inteiro, ele participa, ele colabora com outros no desempenho de suas responsabilidades. Ele enfrenta a adversidade natural entre a inércia e a atividade. Se os manuais da organização científica do trabalho não reconheciam essa participação, isso é outra coisa. O que se faz de fato introduzindo esse vocabulário? Desestabiliza-se um meio de valores, para se introduzir outros que desestruturam e confundem as relações que se dão no lugar de trabalho. Insinua-se uma promessa que não se pode cumprir.

\section{Comunicação e trabalho como atividade humana}

Ao afirmarmos que comunicação e trabalho compõem-se como facetas intrínsecas à atividade humana, estamos confrontando certo idealismo que desvincula a comunicação da atividade de trabalho. Até mesmo na história do desenvolvimento do corpo humano há marcas de que o surgimento de um tipo de comunicação se deu no período em que o hominídeo tornouse caçador ${ }^{19}$. A utilização da mão, liberada para a caça e a coleta, potencializando o desenvolvimento do cérebro e a transformação da boca e da caixa craniana, faz parte do processo que fez do homem um ser de comunicação. A comunicação é uma conquista da espécie humana, efetivada pela 
condição do homem de sobrepor-se, por meio de sua atividade de trabalho, às infidelidades da natureza.

Léontiev (1976, p. 78, tradução da autora) afirma que: “O nascimento da linguagem não pode ser compreendido senão em relação à necessidade $(. . .)^{\prime \prime 20 . ~ E ~ f a z ~ a ~ s e g u i n t e ~ p e r g u n t a: ~ C o m o ~ s e ~ f o r m a m ~ a ~ p a l a v r a ~ e ~ a ~ l i n g u a g e m ? ~}$ A resposta nos envia a trabalho e a comunicação.

"No trabalho, os homens entram inevitavelmente em relação, em comunicação uns com os outros. Na origem, suas ações, propriamente o trabalho, e sua comunicação formam um processo único. Agindo sobre a natureza, os movimentos de trabalho dos homens agem igualmente sobre os outros participantes na produção. Isto significa que as ações do homem têm nessas condições uma dupla função: uma função imediatamente produtiva e uma função de ação sobre outros homens, uma função de comunicação"21 (Léontiev, 1976, p. 78, tradução da autora).

Para Léontiev, linguagem e trabalho estão ligados desde a origem à atividade produtiva, à "comunicação material dos homens". Ou seja, a atividade para a sobrevivência, no enfrentamento das 'infidelidades do meio', requer a comunicação entre os seres para que haja cooperação e, por conseguinte, superação das dificuldades. Dessa forma, a linguagem não é só um meio de comunicação entre os homens, ela é um meio e uma forma da consciência e do pensamento humanos.

Lev Vygotski, professor de Léontiev, tem uma obra clássica que discute sobre a relação pensamento conceitual e linguagem verbal no desenvolvimento da criança. Em uma de suas conclusões afirma:

“O pensamento verbal não é uma forma de comportamento natural e inata, mas é determinado por um processo histórico-cultural e tem propriedades e leis específicas que não podem ser encontradas nas formas naturais do pensamento e da fala. Uma vez admitido o caráter histórico do pensamento verbal, devemos considerá-lo sujeito a todas as premissas do materialismo histórico, que são válidas para qualquer fenômeno histórico na sociedade humana" (Vygotski, 2005, p. 63).

As afirmações de Léontiev e de Vygotski possibilitam compreender a relação linguagem e trabalho como características que se desenvolvem no processo de humanização do homem e, simultaneamente, dando ao homem a especificidade do psiquismo de ser um animal humano. As assertivas dos respectivos autores também permitem esclarecer o polêmico ponto de vista enunciado por J. Habermas 22 (1999), ao defender a prioridade da linguagem em detrimento do trabalho. $\mathrm{O}$ autor quer contestar o conceito de materialismo histórico e para tal recorre ao pragmatismo lingüístico e afirma o caráter primeiro da comunicação em relação à divisão do trabalho. No entanto, nos 
parece que esse ponto de vista é limitado, porque requer separar duas características inseparáveis: a ação do homem pela sua sobrevivência material e defesa física (atividade de trabalho), ou seja, a ação de transformar um meio infiel em um meio para a vida, da característica que essa mesma ação tem à medida que é ela que cria as condições para o aparecimento da linguagem e para o psiquismo específico do ser humano.

A linguagem verbal não tem a primazia que se quer dar a ela em relação à atividade de trabalho. Quando se fala em primazia da linguagem, fala-se no deslocamento da relação objetiva homem em atividade com o seu meio, para afirmar a subordinação do homem ao 'espírito' criador da realidade que ele interpreta. Se o real, e daí a atividade humana singular, não pode ser totalmente antecipado, isto significa afirmar que pensar, conhecer e falar sobre o mundo são 'produtos' da atividade. É afirmar a existência objetiva do sujeito - corpo-si - ser de vontade, de possibilidade de escolha, capaz de transformação, um ser histórico. Um indivíduo social (corpo-si), cuja particularidade se constitui no processo histórico-cultural.

É a partir dessa acepção que podemos compreender o que nos diz Daniel Faïta (2003). Para ele, o discurso (activité langagière) é o que mais se aproxima da atividade de trabalho. Colocar em palavras a atividade é criar um meio próprio, é se apropriar do espaço e do tempo em que se trabalha.

"Pensar é operar muitas linguagens", afirma Faïta, "e a atividade de linguagem é sempre uma operação a posteriori" (2006, tradução da autora)23. Ela acompanha, comenta, projeta a atividade de trabalho e, como afirma Bakthin (1988), é uma arena das lutas sociais. Ela reflete e refrata as menores mudanças sociais.

A palavra é arena das lutas sociais porque se forja na dialética entre o estabelecido e o vir a ser. A palavra é sensível à mais ínfima mudança social porque é como 'unha e carne' da atividade de trabalho.

A relação intrínseca entre comunicação e trabalho permite definir a atividade de trabalho como a gestão de si por si mesmo e de si por outros, a partir do embate entre normas, regras e leis - que estabelecem procedimentos e protocolos; e o ineditismo da atividade real propriamente dita, cuja efetivação re-normaliza (reelabora - mesmo que no microcosmo) cada ato desempenhado pelo ser que trabalha. Neste encontro, forjam-se a experiência e os novos conhecimentos, os novos protocolos. Essa dialética se estabelece por meio de escolhas: gestos, força física, expressão, ritmo, concentração, palavras etc., as quais se objetivam na atividade. Escolhas que vão se configurando como um conjunto de 'valores', cuja lógica pode ser a da economia do corpo e da atenção; ou aquela do maior rendimento do bem produzido; ou aquela da ética, da moral; ou do valor monetário; ou ainda a conjunção de todas elas. São as escolhas que vão sedimentando os valores, 
os quais, por sua vez, orientam a atividade de trabalho e, dessa mesma forma, a comunicação.

Schwartz explica que a abordagem ergológica permite compreender a presença da dimensão de escolhas e de valores na atividade de trabalho. Ao fazermos escolhas, estamos revelando os valores que circunscrevem nossa atividade e como nos situamos na sociedade. Schwartz fala de valores mercantis, não-mercantis, valores contábeis e valores não-mensuráveis, sem dimensão (por exemplo, a saúde). Em suas palavras:

“(...) a abordagem ergológica cujo núcleo comum é encontrar em todas as circunstâncias da atividade normas antecedentes e variabilidades a gerir, normas que se impõem à e normas que se instauram na atividade; esta abordagem é também uma constatação de que a análise rigorosa do trabalho, no sentido mais amplo e disponível ao campo dos valores, epistemologia e ética não são separáveis. Lugar universal de escolhas e arbitragem, a atividade industriosa é sempre destino a viver, engajamento de pessoas; no quadro do nosso espaço tripolar, é confrontação sempre problemática entre valores mercantis e não-mercantis, valores contábeis e valores sem dimensões"24 (Schwartz, 2000c, p. 715, tradução da autora).

Estudar o mundo do trabalho e a atividade de trabalho por meio da linguagem e da comunicação dos sujeitos (corps-soi) é a maneira mais eficiente de se aproximar da realidade do trabalho, dos seus desafios, dos conflitos que permeiam seu ambiente; as dificuldades em gerir as impertinências das condições de trabalho e de como tentar superá-las.

Quando se fala do discurso de máscara dos políticos, dos economistas e dos empresários, por exemplo, se ressalta exatamente como a retórica pode servir à elaboração de um discurso que tenha coerência e coesão internas, mas que, muitas vezes, não condiz com o que a experiência das pessoas registra. O mesmo acontece quando se pretende simular um discurso democrático e participativo dentro das organizações empresariais; ele perde em sentido porque não condiz com o aprendizado que a atividade de trabalho revela. Não há política de comunicação que possa dar suporte a discursos que vão à contramão da experiência adquirida na atividade de trabalho e na atividade de linguagem no trabalho.

As relações de comunicação que se dão no mundo do trabalho demonstram a ineficácia dos discursos oficiais, representativos da norma e da hierarquia institucional. Ineficazes quando se pretendem os únicos a poderem circular no meio de trabalho. Quando desconsideram que o processo de comunicação é criativo, pois pressupõe o sujeito (corpo-si). E este corpo-si em atividade de trabalho é pleno de história e experiência; esforça-se todo o tempo para transformar o lugar de trabalho em seu lugar de trabalho, com 
seu círculo de relações, suas fontes (recursos e informações) de apoio. O mundo do trabalho é um microcosmo da sociedade, no qual se constituem as relações de poder, a afirmação pessoal e profissional, a solidariedade, a amizade. O mundo do trabalho aparece no discurso dos trabalhadores em todas as pesquisas como a segunda família; para alguns, inclusive, a única família: lá estão os colegas de trabalho. Esse lugar de trabalho ganha atributos pessoais, cuidados particulares, decoração, nome, tudo o que puder torná-lo parte, conjunto, composição do sujeito (corpo-si) que está em atividade de trabalho.

Repito: trabalhar é gerir, isto significa o uso de si por si mesmo e o uso de si por outros; significa fazer do trabalho um meio próprio e construir relações com outros. Redes que estão fora do organograma da instituição e são construídas espontaneamente. A estas redes de relações Schwartz denomina 'entidades coletivas relativamente pertinentes' e as define como:

“(...) entidades no sentido de fronteiras invisíveis que englobam pessoas que pertencem a serviços diferentes, pessoas que se conhecem; coletivos porque lá transitam informações eventualmente nos dois sentidos pelas vias mais diversas pode ser aquela das notas escritas, chamadas de telefone, deslocações, muitas coisas - e finalmente, é fundamental para compreender a qualidade de execução das diversas tarefas solicitadas; são relativamente pertinentes na medida em que são pertinentes para compreender como as coisas acontecem, mas elas são relativamente pertinentes, ou seja, as fronteiras são variáveis; podem variar em função das pessoas, e a história na empresa é feita de uma combinação indefinida de tais fronteiras cujas ligações se constroem e se reconstroem incessantemente. É por isso, uma vez mais, que são apenas relativamente pertinente"25 (Schwartz, 2003, p. 144, tradução da autora).

Das entidades coletivas relativamente pertinentes podem fazer parte diferentes pessoas de escalões da hierarquia da empresa; diferentes funções; pessoas de diferentes áreas e setores. Elas se vinculam pela demanda concreta do trabalho. Estão fora do prescrito pela organização, fazem parte do embate cotidiano e permanente entre norma prescrita e renormalização, se originam e resultam da atividade real de trabalho que busca elementos próprios e criativos para driblar o imprevisto e o inusitado sempre presentes na atividade de trabalho.

Nas pesquisas de recepção que realizamos em diversas empresas, pudemos verificar a existência desses laços colaborativos entre os trabalhadores. Percebemos que essas ligações são mais ou menos estáveis dependendo da proximidade, da afinidade de tarefas, do nível hierárquico dos cargos e funções, além de outros tipos de afinidades, por exemplo, a religiosa, a sindical, a política, a esportiva etc. Denominamos essa rede de 
relações como 'relações entre colegas de trabalho'. Inclusive, verificamos que têm importância decisiva no processo de comunicação. Schwartz fala das entidades coletivas relativamente pertinentes como zonas de demarcação invisíveis formadas por pessoas que se relacionam em prol de um serviço, tarefa; são dinâmicas e fluidas. Não têm estrutura, são móveis. Existem como exigência da atividade de trabalho; exigência de vida e realização do corpo-si. Aí há similaridade entre o que encontramos nas pesquisas e o que conceitua Schwartz. Precisamos aprofundar a observação para melhor compreendermos o funcionamento e a importância dessas 'entidades'. Os dados que temos indicam que os laços que se estabelecem entre colegas de trabalho adquirem importância além da realização da tarefa ou serviço. Esses laços são fundamentais para a valorização da própria atividade de trabalho realizada por um determinado sujeito (corpo-si); dão a ele reconhecimento e valorização; e podem se estender além do ambiente mesmo de trabalho. Neste sentido, aparecem diferenças entre as 'entidades coletivas relativamente pertinentes' e as relações entre 'colegas de trabalho'. As 'entidades' coletivas são regidas pelas necessidades de realização das tarefas e serviços que fazem parte da atividade de trabalho. Elas transcendem um tempo exato ou restrito, porque portam a memória do 'saber fazer' do trabalho. Compreendo-as como parte da própria cultura real e da memória da organização. Atenção: não se trata da cultura e da memória oficial. Trata-se do real26, do que se cria a partir da atividade. Mas, as relações que elas estabelecem não são por afinidade, são regidas pela demanda real da atividade de trabalho, e não estão previstas na estrutura da organização.

Michele Lacoste, em seus estudos sobre a atividade de linguagem entre equipes de trabalho em hospital, afirma a importância da linguagem na estruturação de coletivos. A autora trata da comunidade de fala e da comunidade discursiva. Para Lacoste, a comunidade de fala resulta da presença, do contato repetido, se forja através do tempo em trocas efetivas e de colaboração. É a capacidade do grupo de falar coletivamente sobre o que lhe concerne. Sobre as comunidades discursivas, Lacoste esclarece que:

\footnotetext{
“Certas 'comunidades de fala' correspondem ao que se pode chamar de 'comunidades discursivas', na medida em que são estruturadas por maneiras próprias de falar, de pensar e de agir, por valores associados à linguagem, por palavras e condutas verbais específicas que unem os membros dessa comunidade e os distingue de outras" 27 (Michele Lacoste, 2000, p. 69, tradução da autora).
}

É essa definição de Lacoste a que mais se aproxima do que verificamos em nossas pesquisas e denominamos de relações entre colegas de trabalho. De toda maneira, é por meio dessas diferentes formações de coletivos de trabalho que circulam os discursos, os valores, as ideologias. A atividade de 
trabalho forja cada uma delas; e, dialeticamente, esses coletivos permitem a atividade de trabalho. Conhecê-los é o desafio colocado para todos que desejam compreender as relações de comunicação a partir do mundo do trabalho 28 .

\section{Um programa de pesquisa cujo requisito é questionar o estabelecido}

Estudar a comunicação no mundo do trabalho permite entender como se dá a resolução de problemas e a partir de que valores as pessoas fazem suas escolhas; como se constituem os coletivos de trabalho que estão fora do enquadramento do organograma da empresa; como se constituem as redes de ajuda e solidariedade na resolução de problemas e tarefas. É, ainda, compreender como o mundo do trabalho transborda de seu meio e abarca outros espaços sociais, tais como a casa, o bairro, a mídia etc.

Trabalhar é, todo o tempo, trabalhar junto (travailler ensemble). O outro está presente seja como parceiro de trabalho, seja representado pelas normas e prescrições da hierarquia, seja pelo conhecimento técnico e tecnológico acumulado ou pela experiência registrada na linguagem. Trabalhar é gerir o uso de si por si mesmo e de si pelo outro, estabelecendo redes de comunicação, formando laços de confiabilidade, construindo valores.

Se trabalhar é sempre trabalhar com o outro e comunicar é relação, troca, reelaboração, podemos afirmar que ambos, comunicação e trabalho, atuam na construção dos conjuntos de valores que se renovam ou se cristalizam a cada escolha feita, a cada decisão do uso de si por si mesmo. As pessoas, a todo o momento, fazem escolhas a partir das condições e dos valores que construíram ao longo de suas histórias de vida, nas relações com o mundo, com o outro e consigo mesmo. Elas criam suas redes de relações e se apropriam dos discursos que circulam no meio de trabalho delas e na sociedade.

Nas palavras de Schwartz:

“[Os outros] Eles estão presentes em você, eles estão presentes na intimidade de suas escolhas e por conseqüência há uma dialética muito profunda não constitutiva de você, mas que trabalha profundamente em você por você mesmo, desta maneira, escolhendo tal ou qual procedimento ou modalidade de ação, você escolhe, de uma certa maneira, a relação com os outros ou o mundo no qual você quer viver"29 (Schwartz, 2003, p. 188, tradução da autora).

A abordagem ergológica de comunicação e trabalho destaca a relação dialética existente entre o micro e o macro-social. Esta perspectiva teórica propicia entender o trabalho em acepção ampla - como atividade humana 
-, permite ao trabalhador e, portanto, ao sujeito ser de comunicação, ocupar o lugar que ele merece nas pesquisas. Nem superestimando suas potencialidades, nem o relegando à condição de massa de manobra, a ser enquadrado pela retórica seja das empresas onde trabalha, seja dos meios de comunicação dos quais se serve.

Assim, faço das palavras de Louis Durrive as minhas, quando ele afirma que:

"Penso que ilustramos aqui o que chamamos no vocabulário da ergologia 'a dialética micro/macro'. Dito de outra forma, nós reconhecemos os jogos de valores, os jogos da sociedade, as escolhas da sociedade nos menores atos de trabalho"30 (Schwartz e Durrive, 2003, p. 119, tradução da autora).

Comunicação e trabalho como binômio possibilita estudos principalmente em dois eixos ou programas de pesquisa: a) com o objetivo de melhor conhecer a atividade de trabalho, portanto, o mundo do trabalho; e b) melhor entender as relações de comunicação, o processo de comunicação, os sujeitos (corpo-si) da comunicação.

A dimensão de comunicação e trabalho como atividade humana singular, resultada de um processo dinâmico na ontogênese e na filogênese da história, requer que nos coloquemos diante da realidade a conhecer de uma maneira mais aberta e menos pretensiosa.

A abordagem ergológica quer destacar a complexidade existente na atividade humana para, no exercício do conhecimento, manter-se coerente e consciente da imensurabilidade e ineditismo do real, cujo conhecimento está sempre em processo. E, por outro lado, trazer à cena o quanto é redutora e dogmática a visão funcional que se tem da atividade de trabalho.

O conhecimento do ponto de vista da abordagem ergológica é um exercício no qual se problematizam os conceitos, friccionando-os na dimensão da experiência, no confronto da norma prescrita e da re-normalização. A ergologia convoca diferentes disciplinas para refletir sobre o trabalho como atividade humana. Ao propor-se como uma abordagem que estuda a atividade humana, a ergologia convoca também um segundo eixo, o qual denomina de saberes investidos, formulados a partir da experiência, ou seja, a força de um saber específico que demanda sobre os problemas da realidade. E ainda convoca um terceiro eixo, que é o do desconforto intelectual, aquele do questionamento, da fricção entre os valores e do diálogo entre os conceitos epistêmicos das disciplinas constituídas e da experiência dos saberes investidos. À relação entre estes eixos, Schwartz denomina de 'Dispositivo dinâmico em três pólos'. O encontro entre eles permite problematizar e conhecer, mesmo que sempre de maneira parcial31, a complexidade da atividade humana e, nesse sentido, a atividade de trabalho. 
Portanto, a ergologia não reivindica um status de ciência, mas o de abordagem teórico-prática capaz de problematizar a complexidade da atividade humana e distinguir os diferentes fatores pertinentes a ela. Propõe uma postura epistemológica que coloca em fricção os conceitos das disciplinas científicas (abstratos, não-aderentes) com os conceitos da experiência (da vida, aderentes) 32 .

Se aplicarmos ao nosso objeto de estudo o dispositivo dinâmico em três pólos da abordagem ergológica, representando-o no esquema de Schwartz, adaptado por Durrive, (2003, p. 269) teremos em termos do nosso objeto de pesquisa a representação que segue no Quadro 1.

\section{Quadro 1}

Dispositivo dinâmico em três pólos

Eixo A - Saberes e valores no universo

Eixo B - Saberes e valores da experiência, científico (savoir institue) (Teorias da adquiridos na atividade (savoir investi).

Comunicação e outras disciplinas)

Eixo C - Pólo de questionamento

Exercício do socratismo (perguntas e respostas) em duplo sentido.

A

C

B

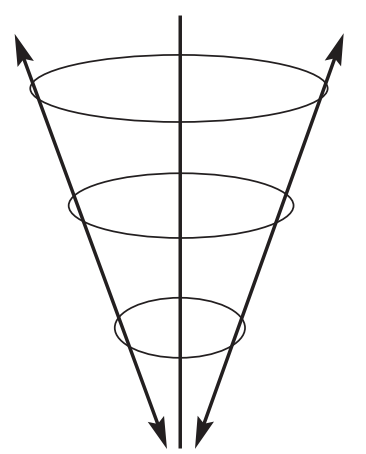

Em nossa aplicação, no eixo A estão os conhecimentos constituídos no campo da comunicação e de outras disciplinas: a filosofia, a psicologia, a sociologia, a antropologia, a lingüística, e que permitem dar forma ao que denominamos de estudos de recepção. No eixo $\mathrm{B}$, temos a atividade concreta de emissão e recepção que todo sujeito faz ao se relacionar com outros, no caso os discursos que circulam no mundo do trabalho (da empresa, dos sindicatos, dos colegas de trabalho etc.). É sempre específica e imensurável. 
No eixo C, temos a formulação do processo de comunicação no mundo do trabalho como um objeto empírico, formulado a partir de questionamentos originados do desconforto intelectual e que se coloca como conhecimento a ser construído na relação entre os diferentes pólos.

A imagem do cone em espiral quer representar a relação micro e macrosocial que toda a abordagem da atividade comporta. E o exercício do questionamento em duplo sentido, que, tensionando os conceitos, (epistemologia/ergologia) possibilita a renovação do conhecimento.

\section{As relações de comunicação nas empresas}

O dispositivo dinâmico em três pólos da abordagem ergológica aplicado às relações de comunicação no mundo do trabalho pode ser identificado como: eixo A - normas, prescrições e discursos da organização; eixo B - saber investido, cultura real dos sujeitos (corpo-si) que estão em atividade de trabalho; e eixo C - questionamento de como fazer melhor em benefício da vida, da saúde física, mental e emocional, e do viver bem em conjunto.

Esse esquema ajuda a visualizar o papel que os responsáveis pela comunicação nas organizações (quaisquer que sejam elas) podem desempenhar ao tomarem para si a responsabilidade de aplicar esse dispositivo. A construção de um saber que leve em consideração a atividade humana - a atividade de trabalho - permite reformular os saberes constituídos e renová-los por meio do questionamento que tem por princípio valorizar e priorizar o pólo da atividade como fonte de possibilidades.

Cabe ressaltar que a proposição da abordagem ergológica do dispositivo dinâmico em três pólos é bastante diferente do proposto por Habermas a partir dos conceitos de ação comunicativa e razão comunicativa. A negociação de definições comuns, tendo a linguagem como meio de intercompreensão, como propõe Habermas, parece muito débil e insuficientemente dialética, afirma Schwartz (2000, p. 84), à medida que o pensador alemão desconsidera a atividade humana de trabalho e remete ao diálogo duas esferas, a do mundo vivido e a do sistema, sem considerar a relação entre atividade, saber (normas) e valores.

O dispositivo dinâmico em três pólos permite, pela força do questionamento, confrontar a norma e a experiência pela atividade de trabalho, revelando os conflitos e as contradições sociais e, principalmente, a potencialidade de transformação do sujeito (corpo-si). Essa proposta permite ainda articular a dialética do micro ao macro-social. Dá condições de se compreender como as transformações no mundo do trabalho se articulam com os valores e as normas sociais e como a realidade do mundo do trabalho transborda para outras instituições e grupos sociais. 


\section{Questionamento em duplo sentido no mundo do trabalho do comunicador}

Os estudos de recepção também têm demonstrado a importância da discussão sobre a atividade de trabalho dos profissionais das empresas de comunicação. Uma aplicação concreta dos resultados das pesquisas acadêmicas poderia retornar à sociedade através da organização de grupos de encontro do trabalho (GET) com os profissionais dos meios de comunicação. A aplicação do dispositivo dinâmico em três pólos pode ajudar a melhor compreender as mudanças que as tecnologias e a organização dos processos de trabalho trouxeram para as profissões do campo da comunicação. Estes grupos de acompanhamento e de discussão da atividade de trabalho não têm caráter fiscalizador. A formação deles, com a participação de pesquisadores e de profissionais da mídia de diferentes funções nas empresas, colocará em diálogo os diferentes saberes e experiências, tendo como objeto de análise a atividade de trabalho nos meios de comunicação; e poderá produzir novos conhecimentos e maior amadurecimento para todos os participantes e interessados no bem comum.

Além de propiciar a discussão e a reflexão sobre a atividade de trabalho, o grupo de encontro do trabalho dos profissionais de comunicação poderá redimensionar a importância e o papel desse profissional na sociedade contemporânea, visto que os meios de comunicação têm importância decisiva em nossa forma atual de organização social.

Quadro 2

Grupo de encontro do trabalho, formulado a partir do dispositivo dinâmico em três pólos da abordagem ergológica

Eixo A - Saberes e valores construídos no Eixo B - Saberes e valores da experiência, universo científico (savoir institue) adquiridos na atividade (savoir investi)

Eixo C - Encontro dos diferentes participantes do GET

Questionamento em duplo sentido, tendo como objeto a atividade de trabalho nos meios de comunicação. Perguntas e respostas para a produção de novos saberes e formas de relacionamento com a atividade de trabalho.

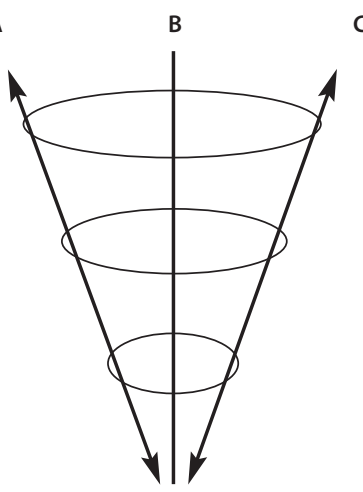


Sobre a caracterização do dispositivo dinâmico em três pólos, Pierre Trinquet, em mensagem transmitida por e-mail a esta autora, em 14 de janeiro de 2007, faz as seguintes observações:

“O dispositivo em três pólos é um dispositivo de pólos e não de estruturas. A diferença é que um pólo se constitui como um lugar virtual, reagrupando formas particulares de saberes e não de pessoas particulares. Dito de outra forma, todo mundo pode estar, por sua vez, nos três pólos. Com efeito, um pesquisador é também um trabalhador e a este título, ele adquire saberes investidos pela sua própria experiência em seu trabalho. $\mathrm{O}$ mesmo ocorre com os atores do trabalho, eles não são desprovidos de saberes constituídos nos seus estudos escolares e/ou suas leituras. Todos os atores do DD3P têm coisas a propor no terceiro pólo. Creio que não é possível personificar os conteúdos dos pólos. Caso contrário, distanciase de algo fundamental"33 (Trinquet, 2007, tradução da autora).

A observação bastante pertinente de Trinquet impede que se caracterizem personagens, cumpridores de papéis fixos, de maneira maniqueísta. O dispositivo dinâmico em três pólos permite exatamente destacar a atividade humana de trabalho como dialética que rege o diálogo para a construção de saberes.

\section{Gestão das relações de comunicação na sociedade}

Outra questão que se coloca é a articulação da atividade de comunicação e trabalho ao nível da sociedade. Como podemos identificar as diferentes características que adquirem comunicação e trabalho quando se trata da comunicação interpessoal (os papéis sociais de cada interlocutor, o lugar de autoridade, relações no mesmo nível etc.), da comunicação institucional (interesses e responsabilidades) e da comunicação midiática, ou seja, dos meios de comunicação geridos pelas empresas de comunicação (que atinge toda a sociedade indiscriminadamente)?

A resposta a esta questão demanda voltarmos ao problema dos valores ${ }^{34}$. Podemos identificar, de maneira geral, dois grandes tipos de valores: aqueles orientados pelos interesses mercantis, quantitativos, mensuráveis, aos quais estão vinculados todos os tipos de interesses do sistema econômico, bem como aqueles do cidadão comum que vende sua força de trabalho e deseja possuir os bens de consumo oferecidos pela sociedade contemporânea; e os valores não mensuráveis, que dizem respeito à vida, ao meio ambiente, aos direitos de igualdade entre os homens, o direito à saúde, à educação, à opinião, à informação, à moradia, ao trabalho, enfim, os valores relativos à dimensão do bem viver em comum. Esses diferentes tipos de 
valores não são estanques. Eles se relacionam por meio das instituições sociais. Estão presentes em cada uma delas e em constante regulação, atrito ou confrontação a depender do perfil de cada instituição e, principalmente, do tipo de instituições políticas e de direito que determinada comunidade tenha construído. Por exemplo, na sociedade brasileira, podemos analisar a relação e a hegemonia de cada tipo de valor presente nas instituições e o papel que joga a política e as instâncias da política na regulação entre eles.

Schwartz afirma que:

“(...) entre estes dois pólos, a compatibilidade é eminentemente problemática, porque eles são orientados por lógicas de criação de meios de vida que não são os mesmos. Portanto, sem dúvida alguma, há problema aí" (Schwartz, 2003, p. 244).

Fazer história, segundo Schwartz, é exatamente o processo de se buscar uma relação política entre esses valores. Relação que privilegie a vida do homem e a sustentabilidade da vida no planeta. Isso passa necessariamente, segundo o autor, pela atividade de trabalho. Inserir o 'pólo' da atividade humana de trabalho - na qual se jogam as dramáticas do uso de si, o debate de normas, a gestão de si e de outro no e do trabalho, a dialética entre o micro e macro-social - poderia explicitar as contradições, realçar e renovar a esfera da política como aquela do bem comum e da igualdade entre as pessoas.

É também nesse sentido que comunicação e trabalho se articulam. Instaurar o pólo da atividade de comunicação e trabalho permite recolocar o embate entre os valores mercantis e os não mensuráveis em uma outra relação. O autor ilustra esse pensamento por meio de um espaço tripolar, no qual se dá o debate de normas numa sociedade mercantil e de direito. Podemos falar de: um pólo da 'dimensão da atividade de trabalho' como trabalho subsumido às trocas e regras do sistema econômico e jurídico; um outro da 'dimensão propriamente de mercado', de prescrição das regras, da mensurabilidade de valores mercantis; e um outro da 'dimensão do viver em comum, das leis e valores' que regem uma sociedade de direito e democrática.

Apropriamo-nos do esquema de Schwartz (Quadro 3) e o adaptamos para demonstrar como esses eixos estão presentes e perpassam as diferentes 'dimensões' de cada organização ou instituição social.

Entendemos que em cada uma das dimensões, explicitadas por Schwartz, existe a atividade de trabalho e de comunicação no nível da comunicação interpessoal; da comunicação institucional; e da comunicação midiática, cuja representação se fez por meio dos pequenos círculos em cada pólo do triângulo representado no Quadro 3. 
Pólo do viver em conjunto como problema comum

Igualdade das pessoas numa sociedade de direito

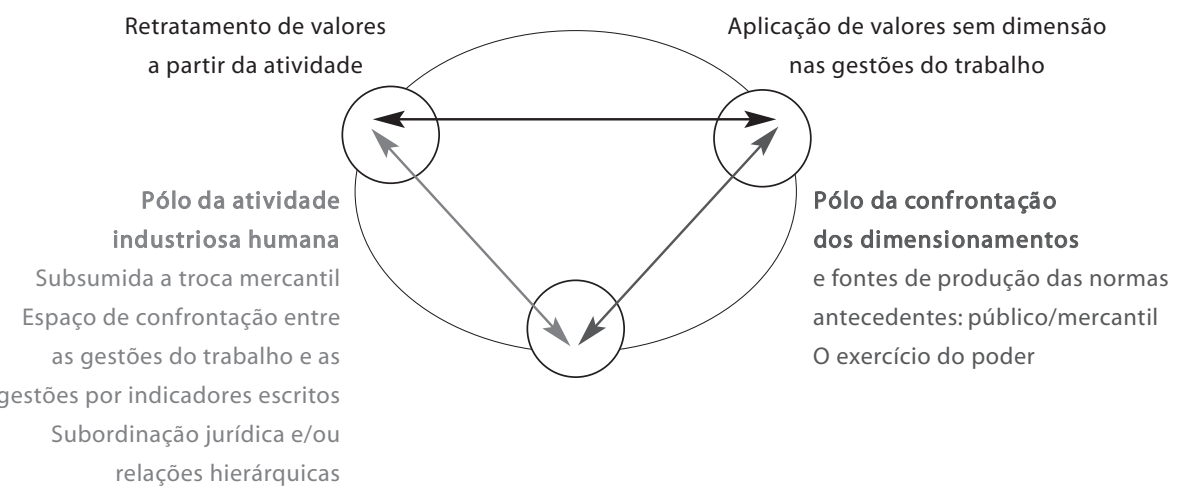

Os pequenos círculos representam a comunicação específica em cada dimensão.

O grande círculo representa a comunicação midiática que circula na sociedade,

cujas empresas de comunicação situam-se no pólo da confrontação público/mercantil.

Esquema de Yves Schwartz, adaptado por Figaro com o acréscimo dos círculos da comunicação.

A comunicação interpessoal no âmbito da organização está diretamente vinculada à atividade de trabalho. A comunicação institucional das organizações é regida pela lógica da hierarquia e dos objetivos mercantis ou das finalidades de cada organização (no caso de organizações públicas ou sem fins lucrativos) e é perpassada pela atividade de trabalho. A comunicação midiática circula por todas as organizações e cada uma das demais formas de comunicação, interpessoal e institucional. A comunicação midiática diz respeito ao conjunto da sociedade, atua em cada um dos pólos - da atividade industriosa, da confrontação do público e do mercantil, e no pólo do viver em comum numa sociedade de direito.

A comunicação midiática no Brasil tem especificidades, porque hegemonicamente é produzida por empresas que atuam no mercado e têm um produto à venda (informação) como outras empresas quaisquer, embora a Constituição Federal trate da informação, da arte e da cultura como um direito do cidadão. Por isso, elas ocupam um lugar determinado nesse esquema de pólos. Localizam-se, como as demais empresas, no pólo da confrontação público/mercantil (embora todas elas tenham as três dimensões já citadas). É deste lugar que elas produzem suas falas, ou seja, os produtos midiáticos. No entanto, como produzem produtos muito especiais - a informação cultural - suas falas parecem originar-se de um outro lugar, como se 
se localizassem na dimensão do viver em comum, das leis e dos valores não mensuráveis.

Quando não existem organizações voltadas para a comunicação pública, a sociedade padece com a supervalorização do pólo da confrontação do público/mercantil. Isso leva ao desequilíbrio entre os pólos. Tal desequilíbrio manifesta-se em todas as demais instituições e organizações da sociedade. Esse desequilíbrio também aparece na produção cultural. Resulta na sobrevalorização do entretenimento como matriz que dá forma ao jornalismo, à publicidade, à ficção, além de outras modalidades de discurso. A diversidade de pontos de vista e de estéticas fica empobrecida. Há prejuízo da dimensão dos valores não mensuráveis, do viver bem em comum. Fator que acaba por prejudicar a própria organização ou empresa.

Quando se colocam estes problemas para serem tratados a partir da atividade dos diferentes sujeitos envolvidos, elucidam-se os valores e as escolhas que deram origem aos resultados (os produtos culturais, distribuição, circulação). Aparecem quais pólos de valores são hegemônicos e se colocam as possibilidades de se escolher reorientá-los. Esse diálogo é difícil, conflituoso e traz para as organizações e movimentos sociais o desafio e a responsabilidade do questionamento para que se encontrem propostas alternativas. Para tanto, é fundamental a participação efetiva dos diferentes envolvidos na atividade ou relacionados a ela.

Mais uma vez, podemos comentar a diferença entre o aqui exposto e a proposta enunciada por Habermas por meio da razão comunicativa. A diferença, segundo Schwartz (2000, p. 702, tradução da autora), é a falta, em Habermas, de uma concepção que considere a atividade humana de trabalho, e uma "verdadeira matriz de história" atenta à dialética entre o local e o global35. Por fim, trata-se de transformar uma prática a partir da consciência de que a atividade humana de trabalho pressupõe escolhas e valores que regem a vida em sociedade. Tal consciência pressupõe considerar a atividade de trabalho como aquela capaz de transformação. Não levar isso em conta reduz o problema do viver bem em comum a uma questão retórica, de trocas lingüísticas. Reduz a comunicação a estratégias de persuasão.

\section{Considerações finais}

Discutimos, inicialmente, como as teorias de comunicação são formuladas, no século XX, no contexto das idéias de fluxo de informação, orientado pelo progresso tecnológico e similar aos organismos biológicos; e nos parâmetros de uma crítica à sociedade de massa e à reprodutibilidade técnica. Formulações teóricas que só podem ser compreendidas no contexto mais geral das mudanças que se operaram no decorrer do período com a organização 
das grandes cidades e das mudanças no processo produtivo. Tais explicações teóricas são similares à linearidade do modelo taylorista de organização do trabalho. Diante dos limites de tais concepções para a atualidade, apresentamos a formulação da abordagem ergológica de atividade de trabalho como uma possibilidade concreta de melhor compreendermos a importância da comunicação na contemporaneidade, e a incorporamos como a base conceitual para se compreender o binômio comunicação e trabalho.

Os estudos de recepção no mundo do trabalho permitiram formular oportunamente esse binômio e propô-lo como conceito profícuo capaz de proporcionar um saber renovado sobre o campo da comunicação. A abordagem do trabalho como atividade humana permitiu-nos ampliar e aprofundar a problemática conceitual inicial e avançar no sentido de um conjunto de proposições teórico-práticas para o desenvolvimento de pesquisas de comunicação no mundo do trabalho. Tratar da comunicação a partir do ponto de vista da atividade humana recoloca a discussão sobre a relação trabalholinguagem e permite esclarecer e aprofundar a crítica aos conceitos habermasianos de ação comunicativa e razão comunicativa.

Os pressupostos teóricos da abordagem ergológica levaram-nos à compreensão da comunicação como 'atividade' de comunicação e trabalho, cujo objetivo é destacar os dois aspectos específicos e intrínsecos à mesma totalidade: a atividade humana. Sendo que não se pode separar um aspecto do outro. Ambos são responsáveis pela especificidade dos seres humanos em relação a outros animais.

A viabilidade desse conceito de atividade de comunicação e trabalho permite propor uma prática de pesquisa que tensiona os diferentes saberes disciplinares com a experiência vivida, a partir do questionamento orientado pela atividade real de trabalho. Fato que recoloca para cada disciplina uma reflexão epistemológica sensível à vida, à atividade humana e ao caráter de ineditismo do real. Permite também entender como se vinculam dialeticamente atividade humana, saberes constituídos e valores (mensuráveis e imensuráveis). Três aspectos que perpassam as organizações sociais e a sociedade como um todo e nos permitem melhor entender como as escolhas feitas pelos sujeitos (corpo-si), no âmbito do micro e do macro-social, estão conformadas por eles.

Finalmente, as questões epistemológicas e teóricas até aqui discutidas dão sustentação aos procedimentos metodológicos das pesquisas realizadas pelo grupo Comunicação e Trabalho, do Programa de Pós-Graduação em Comunicação da ECA-USP. 


\section{Notas}

1 Professora Doutora da Escola de Comunicações e Artes da Universidade de São Paulo (ECA-USP), São Paulo, Brasil. Pós-doutorado pela Universidade de Provence, França. <figaro@uol.com.br>

Correspondência: Rua Itacema, 366, apto. 61, Itaim Bibi, São Paulo, CEP 04530-051.

2 “(...) on désigne ainsi les auteurs regroupés autour de Gregory Bateson, Paul Watzlawick et Edward T. Hall, qui se sont intéressés à la communication interpersonnelle, à la communication non verbale et aux formes de la communication pathologique."

3 "Le procès de travail - l'activité qui a pour but la production de valeurs d'usage, (...) est la condition générale des échanges matériels entre l'homme et la nature, une nécessité physique de la vie humaine, indépendant por cela même de toutes ses formes sociales, ou plutôt également commune à toutes."

4 Para uma história do uso da palavra ergologia, ver: Origines historiques d' ergonomie et d'ergologie, de François Vatin, 2006. Texte et documents. <www.ergologie.com> (acesso em 24 de novembro de 2006).

5 "Ainsi l'activité des animaux reste toujours dans les limites de leurs rapports biologiques, instinctifs, avec la nature. C'est une loi générale de l'activité animale."

6 “( $(.$.$) des auteurs pensent qu'il existe chez certains animaux une division du tra-$ vail. Généralement ils invoquent les cas bien connus de la vie des abeilles, des fourmis et d'autres animaux 'sociaux'. En réalité, dans aucun des ses cas, il n'y a de réelle division du travail, de même qu'il n'y a pas de véritable travail, processus qui est social dans son essence."

7 “Dans le monde animal, les lois générales qui gouvernent les lois du développment psychique sont celles de l' évolution biologique; lorsqu'on arrive à l'homme, le psychisme est soumis aux lois du développement socio-historique."

8 “ $\mathrm{C}$ 'est dans cet écard prescrit/réel du travail que les ergonomes ont observé un processus universel de gestion de l'aléatoire, de l'incidentel: l'activité en général. Sa forme pouvait être conçue comme travail au sens d'une tension pour ajuster en permanence les contraintes prescrites antecipées (norme, obligations, objectifs) aux ressources réelles disponibles (moyenes, réserves subjectives, choix, valeurs) ainsi qu'aux situations rencontrées."

9 "En traitant de la valeur du travail, on risque toutes les dérives si on oublie qu'il n'est pas une réalité simple, historiquement datée, suceptible de caractérisation unilatérale. Si le travail est identifié sans nuances à un emploi, on fera de la valeur du travail le fait d'avoir une place dans un ensemble de placés qui définirait une société. Cette définition purement extérieure valorise l'integration à telle société et fait bon marché des contenus et processus de toute activité humaine, salariée ou non. Car, entre une action humaine quelconque - travail pour soi, travail domestique, activité ludique, sportive - et un travail économiquement qualifié, il n'y a pas de discontinuité absolue: tous deux sont commensurables à une éxperience, celle d'une négociation problématique entre des normes antécédentes et les normes de sujets singuliers, toujours à redéfinir ici et maintenant." 
10 Anotação de comunicação em aula no Departamento de Ergologia da Universidade de Provence (21 de setembro de 2006).

11 “(...) on ne peut pas postuler l'indépendance de la vie de travail par rapport à la vie personnelle des gens; c'est un tout indissociable dont toutes les parties communiquent de façon permanente..."

12 "Travailler sera toujours affaire de confrontation de l'inteligence humaine aux incertitudes du moment présent."

13 “Le corps-soi, c'est l'histoire, l'histoire de la vie, du genre, de la personne, c'est l'histoire des rencontres toujours renouvelées entre un être en équilibre plus ou moins instable et une vie, sociale, avec ses valeurs, ses sollicitations, ses drames. Le corps-soi est histoire, histoire comme mémoire sédimentée, organisée dans la myriade des circuits de la personne; mais aussi histoire comme matrice, énergie productrice d'inédit : dans la mesure où la visée renormalisante est à la fois imposée à l'être - le milieu 'infidèle', comme 'rencontre' il réclame qu'on se choisisse en choisissant telle ou telle façon de la traiter -, et en même temps requise comme exigence de vie, comme appel en lui de santé, l'outillant sans relâche à essayer de transformer ce qui est objectivament pour lui milieu (umgebung) en ce qui pourrait en faire son milieu (Umwelt)."

14 "Mais la vie, plus précisément l'activité, et bien plus explosivement encore l'activité industrieuse, ne se prêtent pas à cette lisibilité docile. (...) L'activité de travail propose, convoque, impose des choix et des arbitrages."

15 “(...) les dramatiques d'usage de soi pour soi même et pour autri."

16 Conferir o conceito de História de longa e de curta duração em La Méditerranée et le monde méditerranéen à l'époque de Philipe II, de Fernand Braudel, 9. ed., v. 1, Paris: Armand Colin, 1990, p. 16-19.

17 Ação no sentido aristotélico.

18 Dominique Efros defendeu em 2001 seu doutorado na Universidade Paris X, Nanterre, com o tema da participação. Travail, guerre e relations sociales. La participation salarie a une entreprise: entre techinique de gestion, utopie et engagement de soi é o título da tese que problematiza o conceito de participação.

19 Ver A evolução da mastigação, de Luciana H. Oba. Monografia apresentada no Centro de Especialização em Fonoaudiologia Clínica e Motricidade. 1999, p. 17; e A evolução cultural do homem, de V. Gordon Childe, Rio de Janeiro: Zahar, 1966. $<$ www.cefac.br/library/teses $>$ (acesso em 26 de novembro de 2006).

20 “La naissance du langage ne peut être comprise qu'en relation avec le besoin (...)."

21 "Dans le travail, les hommes entrent forcément en rapport, en communication les uns avec les autres. A l'origine, leurs actions, proprement le travail, et leur communication forment un processus unique. En agissant sur la nature, les mouvements de travail des hommes agissent également sur les autres participants à la production. Cella signifie que les actions de l'homme ont dans ces conditions une double fonction: une fonction immédiatement productive et une fonction d'action sur d'autres hommes, une fonction de communication." 
22 Ver Teoría de la acción comunicativa (I e II). Madri: Taurus, 1999. Ver também "Crítica à ação comunicativa e à razão comunicativa: para entender a comunicação no mundo do trabalho". Epitc, Revista de Economia Politica de las Tecnologias de la Informaión y comunicación, v. VI, n. 2, p. 54-64, 2004.

23 Comunicação em sala de aula. Departamento de Ergologia, Universidade de Provence (28 de setembro de 2006): "Penser est opérer beaucoup des langages, donc, l'activité langagière est une operation toujours à posteriori."

24 “(...) l'approche ergologique dont le noyau commun est de rencontrer en toutes circonstances d'activité des normes antécédentes et des variabilités à gérer, des normes qui s'imposent à et des normes qui s'instaurent dans l'activité, cette approche est aussi un constat qu'analyse rigoureuse du travail, au sens le plus large et disponibilité au champ des valeurs, épistémologie et éthique, ne sont pas separables. Universel lieu de choix et d'arbitrage, l'activité industrieuse est toujours destin à vivre, engage des personnes; dans le cadre de notre espace tripolaire, il est confrontation toujours problématique entre valeurs marchandes et non marchandes, valeurs comptables et valeurs sans dimensions."

25 "Entretiens sur l'activité humaine. (...) des entités au sens où il y a des frontières invisibles qui englobent des personnes appartenant à des services différents, des personnes qui se connaissent; collectives parce qu'il transite là des informations éventuellement dans les deux sens par des voies les plus diverses - cela peut être des notes écrites, des coups de téléphone, des déplacements, beaucoup de choses - et finalement, c'est fondamental pour comprendre la qualité d'effectuation d'un certain nombre de tâches demandées; elles sont relativament pertinentes dans le mesure où elles sont pertinentes pour comprendre comment ça marche, mais sont relativament pertinentes, c'est-à-dire que les frontières sont variables; elles peuvent varier en fonction des personnes, et l'histoire dans l'entreprise est faite d'une combinaison indefinie de telles frontières en pointillés qui se construisent et se reconstruisent sans cesse. C'est pour cela encore une fois que c'est seulement relativament pertinent."

26 Cultura oficial é aquela registrada pela missão, pelo discurso dos documentos da organização; a cultura real é aquela fruto do embate cotidiano dos sujeitos que compõem a organização em relação ao discurso da norma, oficial.

27 “Certaines 'communautés de parole' correspondent à ce que l'on peut appeler des 'communautés discursive', dans la mesure où elles sont struturées par des manières propres de parler, de penser et d'agir, par des valeurs attachées au langage, par des mots et des conduites verbales spécifiques qui unissent ses membres et les distinguent des autres."

28 Esse tema merece um artigo específico à medida que ele ajuda a elucidar um problema teórico maior, qual seja: aquele que separa a comunicação na organização no âmbito da informação sobre o trabalho (requerimentos, cartas, prescrições, contratos etc.), destacando o caráter funcional e analisando-a do ponto de vista funcional; da comunicação com a coletividade em trabalho, a comunicação da empresa para com o público interno, esta é analisada em seu aspecto cognitivo, a partir dos conceitos de ritual ou de estereótipos relacionais. Ora, duas concepções teóricas diferentes para explicar a comunicação em uma organização. Como se o sujeito que recebe a norma de trabalho fosse outro diferente daquele que recebe o discurso ritualizado do presidente da organização. Vê-se que o sujeito receptor é completamente menosprezado, tido como incapaz. Como se fosse possível existir uma norma, um ofício, seja qual formato tenha, comunicar algo sem passar pelo crivo do sujeito, sem passar pela atividade. A atividade de trabalho é tida como sinônimo de tarefa, 
e comunicação entendida como formato ou gênero. Nem uma, nem outra estão adequadamente definidas e compreendidas. Exemplo desse tipo de abordagem de comunicação, da qual discordamos, está em "A linguagem nas organizações: signos e símbolos" (Girin, 1996).

29 "Ils sont présents en vous, ils sont présents dans l'intimité de vos choix et par conséquent il y a une dialectique très profonde non pas constitutive de vous, mais qui vous travail profondément vous-même, dans cette façon dont, en choisissant telle ou telle procédure ou modalité d'action, vous choisissez d'une certaine manière le rapport aux autres, ou le monde dans lequel vous voulez vivre, d'une certaine manière."

30 "Je pense que nous illustrons là ce que nous appelons dans le vocabulaire de l'ergologie 'la dialéctique micro/macro'. Autrement dit, nous retrouvons des enjeux de valeurs, des enjeus de société, des choix de société dans le moindre des actes de travail."

31 É importante esclarecer que a parcialidade do conhecimento sobre a atividade humana diz respeito ao ineditismo sempre presente na ação do sujeito; diferentemente da abstração da linguagem matemática, por exemplo.

32 Schwartz trata dessa questão como epistemologia/ergologia, ou seja, a atividade é a baliza para o re-trabalho dos conceitos.

33 Pierre Trinquet é sociólogo/ergólogo colaborador do Institut Ergologie/APST de l'Université de Provence: “Dans le DD3P, il est question de pôles et non de structures. La différence c'est qu'un pôle se conçoit comme un lieu virtuel, regroupant des formes particulières de savoirs et non des personnes particulières. Autrement dit, tout le monde peut-être, à la fois, dans les trois pôles. En effet, un chercheur est aussi un travailleur et à ce titre, il acquiert des savoirs investis par sa propre expérience de son travail. De même, les acteurs du travail ne sont pas dépourvus de savoirs constitués dans leurs études scolaires et/ou leurs lectures. Et tous les acteurs du DD3P, ont des choses à proposer dans le troisième pôle. Je crois qu'il ne faut pas personnifier les contenus des pôles. Sinon, on passe à coté de quelque chose de fondamental."

34 Schwartz (2003, p. 241-292) faz essa discussão no capítulo “L’homme, le marché et la cité", no qual também se encontra o esquema original e do qual nos apropriamos para propor nossa reflexão sobre comunicação e trabalho.

35 “Parce qu'il n'y a qu'une pensée faible de l'activité', au sens développé ici, il y manque une matrice véritable d'histoire, attentive aux dramatiques d'usages de soi de 'personnes', et donc aux processus dialetiques entre le local et le global." 


\section{Referências}

ANTUNES, Ricardo. Os sentidos do trabalho. São Paulo: Boitempo, 2000.

ARAGÃo, Lucia M. de C. Razão comunicativa e teoria social crítica em Jürgen Habermas. Rio de Janeiro: Tempo Brasileiro, 1997.

ARAÚJO, Inês Lacerda. Do signo ao discurso. Introdução à filosofia da linguagem. São Paulo: Parábola, 2004.

BAKHTIN, Mikhail. Marxismo e filosofia da linguagem. São Paulo: Hucitec, 1988.

BENVENISTE, Émile. Problèmes de linguistique générale. Paris: Gallimard, 1966.

BOLAÑO, César R. S. Trabalho intelectual, comunicação e capitalismo. A re-configuração do fator subjetivo na atual reestruturação produtiva. 2003, p. 5. Disponível em: <www.eptic.he.com.br>. Acesso em: 22 mar. 2007.

BOLAÑO, César R. S.; BRITTOS, Valério. (Orgs.). Rede Globo: 40 anos de poder e hegemonia. São Paulo: Paulus, 2005.

BORGES, Maria Elisa S. O rei está $n u$. Tramas e urdiduras por uma gestão do trabalho. Tese de doutorado apresentada no Instituto de Psicologia da Uerj, 2006.

BOURDIEU, Pierre. O campo científico. In: ORTIZ, Renato. Pierre Bourdieu: Sociologia. São Paulo: Ática, 1983.

CANGUILHEM, George. Normal e patológico. 6. ed. Rio de Janeiro: Forense Universitária, 2006.

Milieu et norme de l'homme au travail. Cahiers Internationaux de Sociologia, v. III, 2. anné, France, 1947.

CHANLAT, Jean-François (Org.). O indivíduo na organização. 3. v., São Paulo: Atlas, 1996.
COELHO, Teixeira. Dicionário crítico de políticas culturais. 2. ed. São Paulo: Fapesp/ Iluminuras, 1999.

DEFLEUR, Melvin; BALL-ROKEACH, Sandra G. Teorias da comunicação de massa. Rio de Janeiro: Jorge Zahar, 1997.

DORTIER, Jean-François. La communication: omniprésente, mais toujours imparfaite. In: CABIN, Philippe (Coord.). La comunication. Etat des savoirs. France: Editions Sciences Humaines, 1998. p. 1-19.

(Coord.). Le langage. Nature, histoire et usage. France: Editions Sciences Humaines, 2001.

DURAFFOURG, Jacques. Le travail et le point de vie de l'activité. In: Schwartz, Yves; Durrive, Louis. Travail et ergologie. Entretiens sur l'activité humaine. Toulouse: Octarès, 2003. p.31-68.

ESCOSTEGUY, Ana C.; JACKS, Nilda. Comunicação \& recepção. São Paulo: Hacker, 2005.

EFROS, Dominique. Travail, guerre et relations sociales. La participation salariée a une entreprise: entre techinique de gestion, utopie et engagement de soi. These doctoral. Université Paris X, Nanterre, 2002.

FAIRCLOUGH, Norman. Discurso e mudança social. Brasília: UnB, 2001.

FAÏTA, Daniel. Le langage comme activité. In: Schwartz, Yves; Durrive, Louis. Travail et ergologie. Entretiens sur l'activité humaine. Toulouse: Octarès, 2003, p. 159-184.

Communication et modernisation à l'entreprise. Société Française, n. 37, oct./nov./dec., 1990. p. 26-29.

FIGARO PAULINO, Roseli A. Comunicação e trabalho. Estudo de recepção: o mundo do trabalho como mediação da comunicação. São Paulo: Anita/Fapesp, 2001. 
Crítica à ação comunicativa e à razão comunicativa: para entender a comunicação no mundo do trabalho. Epitc - Revista de Economia Politica de las Tecnologias de la Información y Comunicación, v. vi, n. 2, p. 54-64, 2004.

(Org.). Gestão da comunicação no mundo do trabalho, educação, terceiro setor e cooperativismo. São Paulo: Atlas, 2005a.

O desafio teórico-metodológico nas pesquisas de recepção. Revista e-compós. Associação Nacional dos Programas de Pós-Graduação em Comunicação, ago. 2005 b.

GIRIN, Jacques. A linguagem nas organizações: signos e símbolos. In: CHANLAT, Jean-François (Coord.) O individuo na organização. Dimensões esquecidas. São Paulo: Atlas, v. III, 1996. p. 32-33.

GRAMSCI, Antônio. Obras escolhidas. São Paulo: Martins Fontes, 1978.

Escritos politicos. Lisboa: [s.n.],

1977.

HABERMAS, Jürgen. Teoría de la acción comunicativa (I e II). Madri: Taurus, 1999.

Consciência moral e agir comunica-

tivo. Rio de Janeiro: Tempo Brasileiro, 1989.

HALL, Stuart. Da diáspora. Identidade e mediações culturais. In: SOVIK, Liv (Org.). Belo Horizonte/Brasília: FMG/Hitas/Unesco, 2003.

HORKHEIMER, Max; ADORNO, Theodor. Textos escolhidos. Coleção Os Pensadores. São Paulo: Nova Cultural, 1991.

IANNI, Octávio. Enigmas da modernidademundo. 3. ed. Rio de Janeiro: Civilização Brasileira, 2003.

LACOSTE, Michele. Le langage et la struturation des collectifs. In: BENCHEKROUN,
T. H., WEIL-FASSINA, Annie. Le travail collectif. Perspectives actuelles en ergonomie. Toulouse: Octarès, 2000. p. 55-70.

LÉONTIEV, Alexis. Le développement $d u$ psychisme. 3. ed. Paris: Editions Sociales, 1976.

LEOROI-GOURHAN, Andre. Mécanique vivante. Le crâne des vertébrés du poisson à l'homme. Paris: Fayard, 1983.

LIMA, Vinício. Mídia - Teoria e Política. São Paulo: Perseu Abramo, 2001.

LOPES, Maria Immacolata V. de et. al. Vivendo com a telenovela. Mediações, recepção, teleficcionalidade. São Paulo: Summus, 2002.

LOUBOUTIN, C. Au neolithique - les premiers paysans du monde. Paris: Découvertes Gallimard, 1990.

MARTÍN-BARBERO, Jesús. De los medios a las mediaciones. 3. ed. México: G. Gilli, 1993.

MARX, Karl. Manuscritos econômico-filosóficos. (Tradução de Artur Morão, 1975, a partir de seleção de T. B. Bottomore. Prefácio de Erich Fromm). Lisboa: Edições 70, 1993.

MOLENÁT, X. (Coord.). Qui a peur de la culture de masse? (Dossier). France: Editions Sciences Humaines, n. 170, Avril, 2006.

MORAES, Dênis (Org.). Globalização, mídia e cultura contemporânea. São Paulo: Letra Livre, 1997.

MORIN, Edgar. Cultura de massa no século $X X$. Neurose. 9. ed. Rio de Janeiro: Forense, v. 1, 2005.

PERRIER, Alexandre. De la valeur-travail au travail de valeur. In: SCHWARTZ, Yves. Reconnaissance du travail. Pour um approche ergologique. Paris: PUF, 1997. 
PÊCHEUX, Michel. Semântica e discursoUma crítica à afirmação do óbvio. Campinas: Edunicamp, 1988.

PEIRCE, Charles Sanders. Semiótica. 3. ed. São Paulo: Perspectiva, 2003.

ROSA, Maria Inês. Trabalho, subjetividade e poder. São Paulo: Edusp, 1994.

. Usos de Si e testemunhos de traba-

lhadores. Com estudo crítico da sociologia industrial e da reestruturação produtiva. São Paulo: Letras e Letras, 2004.

SANTANA, Sylvana de C. P; SouzA, Nícia Raies M. Indústrias culturais: geração de trabalho e emprego. In: ALVAREZ, Gabriel O. Indústrias culturais no Mercosul. Brasília: Instituto de Relações Internacionais, 2003.

SCHAFF, Adam. Linguagem e conhecimento. Coimbra: Almedina, 1976. O marxismo e o indivíduo. Rio de Janeiro: Civilização Brasileira, 1967.

SCHWARTZ, Yves. Travail et Philosophie. Convocations mutuelles. 2. ed. Toulouse: Octarès, 1994.

- Reconnaissance du travail.

Pour une approche ergologique. Paris: PUF, 1997.
Discipline episthémique, discipline ergologique. Paideia et politeia. In: MAGGI, Bruno. Manière de penser, manière d'agir en éducation et en formation. Paris: PUF, 2000a, p. 33-68.

SCHWARTZ, Yves; DURRIVE, Louis. Travail et ergologie. Entretiens sur l'activité humaine. Toulouse: Octarès, 2003.

Trabalho e uso de si. Revista Proposições. Faculdade de Educação, Unicamp, São Paulo, n. 32, 2000 b.

Le paradigme ergologique ou le métier de Philosophe. Toulouse : Octarès, 2000c.

SOUZA E SILVA, Maria Cecília P.; FAÏTA, Daniel. Linguagem e trabalho. Construção de objetos de análise no Brasil e na França. São Paulo: Cortez, 2002.

VYGOTSKI, Lev Samenovitch. Pensamento e linguagem. 3. ed. São Paulo: Martins Fontes, 2005.

WOLF, Mauro. Teorias da Comunicação. 2. ed. Lisboa: Presença, 1992.

WOLTON, Dominique. Les sciences de communication aujourd'hui. In: CABIN, Philippe (Coord.). La comunication. Etat des savoirs. France: Editions Sciences Humaines, 1998. p. 49-54.

Recebido em 18/05/2007

Aprovado em 28/02/2008 